\title{
Thoughts on the Status Quo of Rural Tourism Development ${ }^{1}$
}

\author{
Hu Xiaoling 1, 2, a \\ ${ }^{1}$ College of Management, Wuhan Technology and Business University, Wuhan, 430065, \\ China \\ 2 Hubei Business Development Center, Wuhan, 430065, China \\ aemail: 244916944@qq.com
}

Keywords: Rural tourism; Current situation; Thinking

\begin{abstract}
At present, rural tourism in China is developing rapidly. Rural tourism is mainly represented by rural scenery and rural folk customs. Rural tourism is enriching China's tourism industry. This paper analyzes the background of rural tourism development, analyzes the development status of rural tourism in China, and provides reflections on the development strategy of rural tourism to realize the sustainable and healthy development of rural tourism.
\end{abstract}

\section{Introduction}

The rise of rural tourism in China began in the late 1980s, initially in the form of eco-agricultural tourism, and became an important entry point for the combination of the primary industry and the tertiary industry. After the 1990s, China's urbanization construction and social economy developed rapidly, people's life concepts and consumption structures have changed, and there is a higher level of requirements for lifestyle. Since 1995, China's implementation of the weekend system and the three golden week systems of "May 1st", "Eleventh" and Spring Festival, which began in 1999, have promoted the development of tourism in remote rural areas. The development of rural tourism is gradually developing towards a comprehensive direction of tourism, inspection, study, participation, recreation, leisure, vacation, entertainment, etc., but overall it is still in the initial stage of development. After 1998, eco-tourism became popular in China, and farmhouse music began to appear. Rural tourism began to upgrade from a single traditional sightseeing to a participatory tourism. In 2006, the National Tourism Administration launched the China Rural Tourism Year with a new image of new countryside, new tourism, new experiences and new fashions, aiming to promote the great development of rural tourism in China. At present, the development background of rural tourism in China mainly has the following points.

\subsection{Promote the construction of ecological civilization and rural areas}

The goal of harmonious development of rural economy, society and ecology depends on cultivating ecological culture and building a civilized village. The 18th National Congress of the Communist Party of China clearly stated that "the ecological civilization construction should be placed in a prominent position and integrated into all aspects of economic construction, political construction, cultural construction, and social construction, and efforts should be made to build a beautiful China and realize the sustainable development of the Chinese nation." The construction is highly discussed in the overall layout and is very important. Through the solid rural tourism planning and the development of rural tourism, the ecological environment and folk culture of the rural areas will be optimized.

\subsection{Implementation of the new countryside}

The "Proposal for the Eleventh Five-Year Plan" adopted by the Fifth Plenary Session of the 16th Central Committee of the Communist Party of China clearly stated that "production development, ample life, civilized villages, clean villages, and democratic management" should promote the building of a new socialist countryside. Since then, China has been in full swing in the construction 
of new countryside, and the construction of new countryside has become a huge thrust for the development of rural tourism. For example, the state has given support to rural tourism poverty alleviation policies, and rural tourism and new rural construction in rural development have promoted the further development of rural tourism.

\subsection{The quality of life of rural residents has been improved}

In the development of rural tourism, a large number of people, money, and goods flow, local residents have more employment opportunities. China has accelerated the rural poverty alleviation, and the economic living standards of the villagers have been improved. At the same time, the spiritual life of rural residents has been enriched, and the spiritual civilization quality of the rural population has been improved. The long-term sunrise of rural life is a sunset, and the pace of life has improved. Rural tourism promotes the collision and exchange of farming culture and urban civilization. The villagers' views and values have also been transformed. The stakeholders have effectively passed on and innovated the ancient rural culture.

Therefore, the development of rural tourism benefits from the guarantee of national policies, the stability of the national economic environment, the advancement of cultural tourism, and the prosperity of science and technology. Rural tourism has become the inevitable development of tourism in the new era.

\section{Analysis of the Status Quo of Rural Tourism Development in China}

The tourism resources of rural tourism development in China are based on the natural environment and the cultural landscape that is closely related to the human culture and the natural environment. It is a harmonious rural regional complex composed of natural environment, material and non-material elements. The classification of rural tourism resources is shown in Table 2-1.

Table 2-1 Classification of rural tourism resources

\begin{tabular}{llc}
\hline Rural tourism resources & $\begin{array}{l}\text { According to the structure } \\
\text { and combination of tourism } \\
\text { resources }\end{array}$ & $\begin{array}{l}\text { Divided by composition, external } \\
\text { features, internal structure, landscape } \\
\text { function, evolution, etc }\end{array}$ \\
\hline $\begin{array}{l}\text { Village garden landscape } \\
\text { tourism resources }\end{array}$ & Agricultural landscape \\
\hline $\begin{array}{l}\text { Rural settlement landscape } \\
\text { tourism resources }\end{array}$ & Settlement landscape \\
\hline $\begin{array}{l}\text { Rural architecture } \\
\text { landscape tourism } \\
\text { resources }\end{array}$ & Folk culture landscape \\
\hline $\begin{array}{l}\text { Rural farming and cultural } \\
\text { landscape tourism } \\
\text { resources }\end{array}$ & \\
\hline $\begin{array}{l}\text { Rural folk culture } \\
\text { landscape tourism } \\
\text { resources }\end{array}$ & \\
\hline
\end{tabular}

Combined with rural tourism resources, we can analyze the products, prices, channels and promotions of rural tourism. The products and prices of rural tourism, through surveys, found that every time a holiday or tourist season, rural tourist attractions, homestays will increase prices. Here, rural tourism products and prices are worth reflecting. For example, we can give the grassroots staff of the B\&B a certain authorization, and during the holiday season and the peak season, employees can control the price at any time. The rural tourism industry will not have the high price of the wild fishing village on the North Shore, "the domesticated carp transported from Wuhan"; there will be no "one pile of lobsters in front of each person" in Thailand. . In fact, the products and prices of rural tourism are not the killers of tourism. The rural tourism industry needs the creative thinking of "what is coming". Rural tourism prices can take many forms, depending on the level of creativity of rural tourism, adding higher value and experiencing more cultural elements. Therefore, rural tourism prices 
should continue to develop and improve. As for the practice of rural tourism, how the price reflects the authenticity needs to be discussed. Rural tourism products and prices have always been sensitive and fragile, more or less influenced by the market, and particularly outstanding during the peak season.

In the current rural tourism channel, it is a very important mode for rural tourism to open up the rural tourism market. Through the multilateral market or the trilateral market, the channel can be expanded. Usually, the mass rural tourism market can now be sold directly. In the process, rural tourism consumers directly purchase rural tourism products. Indirect channels are conducted through agents or wholesalers. For example, travel agencies can expand the market from the department to the e-commerce, online and offline. Here, the marketing channels of rural hotels can be traditional direct-to-customer sales, and can also be used to create industrial sales channels through e-commerce platforms. In traditional festivals, such as the Mid-Autumn Festival, many rural folklore incorporate many elements of Chinese traditional culture. There is both the authenticity of culture and the reconstruction of creativity. Therefore, it can be seen from the rural folklore that many channels are diversified, and that tradition and modernity coexist. Because of the advent of the Internet era, rural folklore survived, grew and matured in a brutal competitive environment. It can be said that rural folk customs face enormous opportunities and challenges. Therefore, rural tourism channels exist.

Today, rural tourism sales can be done by staff, or B2B mode, or B2C mode. The pattern of rural tourism promotion has undergone tremendous changes. Here, traditional staff can be professionals or non-professionals. However, the traditional sales process needs to communicate with the travel consumers, and how to communicate the products, prices, and even channels to the rural tourism consumers in the process of communicating with others. In the context of the Internet + , many online sales lack creativity. In Ctrip or e-Long or more websites, simply place the same type of B\&B room, marked with the price, it is difficult to see the characteristics of rural tourism products. Open the country house's official website, it is difficult to reflect its innovation. The mode of rural tourism sales, we see Weibo, WeChat, QQ community. . . These virtual sales channels have also formed a certain rural tourism market.

\subsection{The lack of authenticity of rural tourism products}

China's rural tourism has been able to continue to develop through the path of industrialization. The promotion of rural tourism has transformed from a scattered small-scale agricultural model to an intensive model, forming a rural tourism industrialization. Some rural tourism planning adopts urbanization and modern landscape design, paying too much attention to artificial landscape and modernization, ignoring the original natural environment of the village. Ancient trees, streams, natural and quiet architectural environment; original farmland, farmhouses, farming activities, farming culture and living landscape; intangible cultural landscapes such as folk customs and folk art, these rural tourism products are important rural tourism resources. . The design of the reception facilities and product projects for rural tourism deviates from the scenery of the fields, rural folk customs and local flavors. In the process of rural tourism planning and construction, the original rural atmosphere and ecological environment were dismantled and damaged, resulting in the waste and destruction of rural tourism resources, and the lack of natural and human elements of rural tourism.

\subsection{Insufficient design of rural tourism products}

There are a large number of rural areas in China, which are rich in natural ecological resources and human landscape resources. Therefore, rural tourism products can show local folk customs and rural tastes according to local conditions and seeking truth from facts. However, some rural tourism products are not well designed, the profit model is single, the tourism projects are monotonous, the supporting facilities are imperfect, and the connotation of rural culture cannot be reflected, and the cultural connotation and core competitiveness unique to rural tourism cannot be reflected. The tourism product project is limited to simple farming experiences such as eating farmhouse meals, living in farmhouses, and doing farm work. For example, the natural and human elements of rural tourism products are not prominent, the product content is not rich, and the product complementarity is not strong enough to meet the diversity and individual needs of tourists. At present, on the one hand, the demand for rural tourists is multi-level, diversified and high-cultural tourism demand. On the 
other hand, there are reproduction phenomena in rural tourism products in China, and the development of rural tourism is seriously restricted.

\subsection{Insufficient efforts in rural tourism social protection}

The development of rural tourism in China has produced a large number of economic benefits, and the economic living standards in rural areas have been improved. The important means for rural farmers to get rid of poverty is to promote poverty alleviation. However, some rural natural and human ecological environments have been destroyed because of over-emphasis on economic interests in the development of rural tourism. The development of rural tourism has strongly impacted the traditional customs and values of rural residents and undermined the social environment of the countryside. Driven by economic interests, the government authorities have insufficient restrictions on the environmental capacity planning of rural tourism. In some areas, a large number of tourists flooded into the scenic spots, resulting in traffic congestion, public security problems, cultural conflicts, etc., which seriously interfered with the normal production and life of rural residents, leading to negative sentiments of villagers on rural tourism. Due to the neglect of rural tourism planning, neglecting the participation of farmers and the improvement of their quality of life, the uneven distribution of the interests of rural residents and the emergence of tourist enclaves. In this way, the rural tourism has intensified the dissatisfaction of the villagers, which has further led to the vicious destruction of the social environment in the rural tourist areas. Therefore, stakeholders in rural tourism should coordinate the relationship between the government, scenic spots, villagers and tourism developers, and strengthen the environmental protection of rural tourism.

\subsection{Rural tourism management is not smooth}

The basis for the sustainable development of rural tourism is scientific planning. Most rural tourism in China employs a special tourism planning team to carry out scientific and in-depth planning and preparation, highlighting the theme image of the rural tourism products and the positioning of the theme products. The preparation of rural tourism planning at this stage should be fully investigated and approved by local leaders and relevant departments. However, some rural tourism designs have a multi-headed management phenomenon, and there are certain links and disputes between local villagers, planning developers, local governments, and tourism departments. This led to the rural tourism planning team, the design and development of rural tourist attractions, etc., can not be effectively implemented, and the opinions of interest groups and management units are also not uniform. The opinions between the various units are not unified, hindering the design of rural tourism planning, and even pushing forward the problems in the implementation process of rural tourism planning, reducing the design level of rural tourism planning and hindering the implementation of planning.

Therefore, in the development of rural tourism, there are insufficient originality of tourism products, inadequate design of rural tourism products, insufficient environmental protection of rural tourism, and unsatisfactory management of rural tourism. In China, the current situation of rural tourism mainly focuses on the development and design of tourism products, as well as the policy resources and management of rural tourism. Today, in the development of rural tourism, there are also many successful rural tourism cases, such as Xidi Hongcun in Anhui, Wuyuan in Jiangxi, and Zhouzhuang in Zhejiang.

\section{Countermeasures and suggestions for the development of rural tourism}

In the process of rural tourism development, we can adopt local adaptation methods, combine local folk customs, and carry out tourism activities with local cultural connotations to unify the development and protection of tourism landscapes, and realize the green, ecological and environmental protection of rural tourism. Continue to develop.

How to develop and protect rural tourism development? When visitors enter a scenic spot, they go to experience and they go to leisure. Tourist attractions may be works of nature or artificial landscapes. For example, some tourists said: "When I enter Changbai Mountain Scenic Area, I feel 
that I am a vulgar from the city. The scenic spots of Changbai Mountain are very interesting for the elderly and children." For example, some tourists said: "I am going to take a child to enter Changlong in Guangzhou during the summer vacation. In the water park, the children are very happy." Of course, the two tourists said from two aspects, one is completely conquered by the natural landscape of nature, and the other is attracted by the artificial scenery after the transformation. Here, it can be said that tourism products can influence the perception, identity and values of tourists. Regardless of nature or humanity, tourists experience and experience, and tourism products are consciously and processed. Do these tourist attractions exist in the true nature or in the form of symbols and spiritual values? At the hotel, visitors go to taste the food, the utensils of these foods, the taste and color of the food. . . There are eight major cuisines in Chinese food. With the progress and development of the society, the catering department is basically pursuing the original taste when it launches its products. In fact, it is also a simple authentic experience. For example, in the self-owned village where Kaiping is located, some local residents sell some agricultural tools and sell their own local products. There are many tourists who come here and still buy some products. Here, we can see that rural tourism products are authentic on the one hand, and on the other hand have to cater to the needs of tourists, it can be said that rural tourism products are maintained.

\subsection{The authenticity protection of rural tourism products}

While carrying out rural tourism construction, it pays attention to environmental protection and the authenticity protection of rural tourism products. The authenticity protection of rural tourism products in China ensures the protection of the original nature of traditional culture and human heritage. At the same time, the importance of the protection of the authenticity of the rural folk customs is to educate the residents and raise the awareness of the local culture.

\subsection{Rural tourism product design meets the needs of tourists}

The design of rural tourism products needs to design tourism products with local cultural characteristics and local cultural atmosphere from the perspective of tourists. For example, some tourism products should promote China's traditional rural atmosphere and local flavor, so that tourists can repeat purchases.

\subsection{Strengthening the social protection of rural tourism}

Strengthening the environmental protection of rural tourism society can strengthen coordination from the government, tourists, developers, and local residents. For example, the behavior of foreign tourists is critical to the authenticity of tourism products. During the development of rural tourism, the local government is reminded to guide and enable foreign tourists to consciously protect the environment of rural tourism, so as to obtain the most authentic and unique tourism experience.

\subsection{Improve Rural Tourism Management}

In China, the government plays a leading role in the development of rural tourism, and through the formulation of relevant regulations and measures to achieve the government's macro-control and protect rural tourism. In the development and construction of rural tourism, the implementation of protection is the core principle. Projects that do not meet the requirements for environmental protection will not be resolutely handled. Relevant departments should seriously investigate and punish those responsible for the destruction of resources and the environment in accordance with relevant laws and regulations. For the protection of ethnic folk culture, it is expressly stated that it calls for and regulates the protection of local people and foreign tourists. Under the premise of establishing a rural tourism security system, it pays attention to the development of tourism products and provides tourists with a real tourism environment.

\section{Acknowledgement}

This work was financially supported by Hubei Business Development Center project "Research on the Development Path of Rural Tourism from the Perspective of Ecological Civilization "( 2017Y002) 
one of the stage results.

Hubei Business Development Center project "Research on the Development Path of Rural Tourism from the Perspective of Ecological Civilization"( 2017Y002) one of the stage results

\section{References}

[1] Lepp A. Tourism and dependency: An analysis of Bigodi village, Uganda, Tourism Management, 2008, 29(6):1206-1214.

[2] Royo-Vela M. Rural-cultural excursion conceptualization: A local tourism marketing management model based on tourist destination image measurement, Tourism Management, 2009,30(3): 419-428. 